\title{
We-The-Women: A Generation in Transition? The Agni-Pareeksha is on!
}

\author{
Indu Rao* \\ Institute of Management, Nirma University, India
}

Submission: August 28, 2018; Published: September 14, 2018

*Corresponding author: Indu Rao, Human Resource Management Area, Institute of Management, Nirma University, India, Tel: 079-30642647; Email: indu@nirmauni.ac.in

Keywords: Women; Transition; Generation; Family life; Wrath; Concern; Care; Jealousy; Insecurity; Challenges; Agni-pareeksha; World; Decade; Test of Fire; Queen

\section{Opinion}

Recently, I visited Mumbai, Hyderabad and Chennai, major cities in India, on different academic assignments and met exceptional women who enjoy their family life as well as their work identity outside home, in academic professions. During the past decade, I had opportunity to interact with successful women from the West, pursuing successful professions in academics. In different parts of the world, women have achieved this feat while learning to deal with universal challenges. I tried to classify these challenges:

i. Wrath (Anger) of those who believe that women don't deserve to and are not meant to have best of both worldsfamily as well as the world outside home. Such people threaten and prevent women from doing this.

ii. Concern (Care) of those who believe it is not possible to have both. And that it will be painful so why try for it.... they advise women to enjoy family life and the comfort of home if we have it...and to let go of family hassles if work is giving us a comfortable life.... doing both not possible.

iii. Jealousy (Insecurity) of those at home and at workplace (the worst of all) those who are simply not happy if women enjoy both, a family life and an identity outside home because it threatens their own ego and ecosystem. Such people do all sorts of politicking at workplace to pull down and harass this generation of women and sadly, it comes from both, men and women.

Nevertheless, to meet the above challenges, women over the years have given "agni-pareeksha" at different times...trying to prove themselves in different ways/ roles ...both at home in outside with inherent struggle, survival and success....and have paved way for the next generation of aspiring women ....'Agni Pareeksha' in Hindi language means a "test of Fire". When there was a question of chastity of Goddess Sita, from Indian mythology, she stood inside fire and prayed to prove her purity and devotion to her husband 'Lord Ram". She was of course vindicated and mother earth engulfed her as she was born out of mother earth, as the story goes. In India, even today, women swear by Goddess Sita to uphold the chastity of a wife. In another story that has passed from generations to generations, Rani Padmini, the Queen, burnt herself alive along with several other women of a Fort in Rajasthan, India when all men were killed by the enemy, to save themselves from being molested.

Modern women continue to face questions of their conduct and character and are required to prove themselves one way or the other. But the new generation is different. No, ...we are not waiting to be engulfed by mother earth, like Goddess Sita, nor to commit a jauhar like Rani Padmini (now Padmawati). No, we are also not feminists, nor activists, we don't have unions to fight for nor we depend on/ ask help from anyone else.... we're not ambitious leaders, yearning to control the lives of others...this is also not about beti bachao beti padao.... it's a different issue ....an issue of what next?

We are simple and educated women... a generation in transition... who simply wish for/ and have a reasonable control over our own lives...to be able to live with dignity both inside home and outside home and be happy.... even this is threatening to some people? We know and must acknowledge that contribution from the talent of women (half of our population) adds value to the entire society and not just to homes.... why then all the horror stories that we hear these days as crimes against Women? at home and at workplace and in transit??? Let women live and work and choose what they want to do.

Challenges are there, but regardless........We-the- Women are a generation in transition.......and on a positive note.... we are networking and our number is increasing...!!! 
This work is licensed under Creative Commons Attribution 4.0 License Commons Attribution 4.0 License

\section{Your next submission with Juniper Publishers} will reach you the below assets

- Quality Editorial service

- Swift Peer Review

- Reprints availability

- E-prints Service

- Manuscript Podcast for convenient understanding

- Global attainment for your research

- Manuscript accessibility in different formats ( Pdf, E-pub, Full Text, Audio)

- Unceasing customer service

Track the below URL for one-step submission https://juniperpublishers.com/online-submission.php 